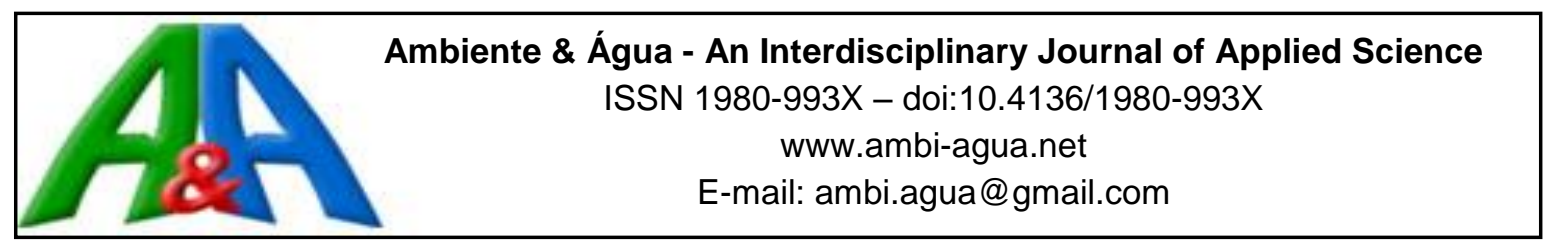

\title{
Ozonation improves physical attributes in domestic sewage effluent
}

\author{
ARTICLES doi:10.4136/ambi-agua.2328
}

Received: 13 Sep. 2018; Accepted: 24 Jan. 2019

\author{
Osli Barreto Camilo Júnior ${ }^{*}$; ; Delvio Sandri ${ }^{\circledR}$; \\ Ernandes Rodrigues de Alencar $^{2}$; ; Lucas Ferraz Hebling ${ }^{2}(D$ \\ ${ }^{1}$ Universidade de Brasília (UnB), Brasília, DF, Brasil \\ Faculdade de Agronomia e Medicina Veterinária (FAV/UnB). \\ Programa de Pós-Graduação em Agronomia. E-mail: oslijr@gmail.com \\ ${ }^{2}$ Universidade de Brasília (UnB), Brasília, DF, Brasil \\ Faculdade de Agronomia e Medicina Veterinária (FAV/UnB). E-mail: sandri@unb.br, \\ ernandesalencar@unb.br, hebling123@gmail.com \\ *Corresponding author
}

\begin{abstract}
Root Zone Wastewater Treatment (RZWT) is an option of natural wastewater treatment widely studied throughout the world, being a technology based on physical, chemical and biological processes. However, there are some attributes in effluent that occasionally are not eliminated by RZWT. In this context, the use of ozone may contribute to mineralization, disinfection, detoxification, and, especially, color and turbidity removal. Ozone is an excellent oxidant, with great potential to reduce color, turbidity and other attributes in liquids, such as in wastewater treatment. This paper evaluated the effect of different ozone exposure times $(0,30$, 60, 90, 120 and 150 minutes) and the application of different dosages of ozone $(0,4,10,17,25$ and $35 \mathrm{mg} \mathrm{L}^{-1}$ of $\mathrm{O}_{3}$ ) on Hydrogeonic Potential (pH), Electrical Conductivity (EC), Dissolved Oxygen (OD), Total Alkalinity (Alk.), Sodium (Na) and Potassium (K) in domestic sewage effluent treated by the RZWT. Different exposure times and ozone dosages did not influence the attributes Potassium, Sodium, Ammonia and Total Solids. Color and turbidity decreased, while $\mathrm{pH}$, Alkalinity and Dissolved Oxygen increased at all exposure times and $\mathrm{O}_{3}$ dosages in relation to the non-ozonized effluent.
\end{abstract}

Keywords: color, ozone, root zone wastewater treatment, turbidity.

\section{Ozonização promove a melhoria de atributos físicos em efluente de esgoto doméstico}

\section{RESUMO}

O Sistema de Zona de Raízes (SRZ) é uma opção natural de tratamento de efluentes amplamente estudado em todo o mundo, sendo uma tecnologia baseada em processos físicos, químicos e biológicos. No entanto, existem alguns atributos no efluente que ocasionalmente não são eliminados pelo SZR. Nesse contexto, o uso do ozônio pode contribuir para a mineralização, desinfecção, desintoxicação e, principalmente, remoção de cor e turbidez. $\mathrm{O}$ ozônio é um excelente oxidante, com grande potencial para reduzir a cor, a turbidez e outros atributos em líquidos, assim como no tratamento de efluentes. O objetivo deste trabalho foi avaliar o efeito de diferentes tempos de exposição ao ozônio (0, 30, 60, 90, 120 e 150 minutos) e a aplicação de diferentes dosagens de ozônio $\left(0,4,10,17,25\right.$ e $35 \mathrm{mg} \mathrm{L}^{-1}$ de $\left.\mathrm{O}_{3}\right)$ sobre 
Potencial Hidrogeônico (pH), Condutividade Elétrica (CE), Oxigênio Dissolvido (OD), Alcalinidade Total (Alk.), Sódio (Na) e Potássio (K) no efluente doméstico tratado pelo SZR. Diferentes tempos de exposição e dosagens de ozônio não influenciaram os atributos Potássio, Sódio, Amônia e Sólidos Totais. A cor e a turbidez diminuíram, enquanto o pH, a alcalinidade e o oxigênio dissolvido aumentaram em todos os momentos de exposição e as dosagens de $\mathrm{O}_{3}$ em relação ao efluente não-ozonizado.

Palavras-chave: cor, ozônio, sistema de zona de raízes, turbidez.

\section{INTRODUCTION}

The use of septic tanks, followed by Root Zone Wastewater Treatment (RZWT), is an option of natural wastewater treatment system widely studied throughout the world, being a technology based on physical, chemical and biological processes which normally occur naturally in ecosystems, such as in natural floodplains (Kadlec and Wallace, 2009).

The main function of a wastewater treatment system is to remove the pollutant load, whether colloidal or soluble compounds. However, some attributes in the effluent occasionally are not eliminated. In this context, the use of ozone may contribute to mineralization, disinfection, detoxification, and, especially, color and turbidity removal (Bhatta et al., 2015).

Today, ozone is still used for disinfection, but due to its superior oxidizing ability it is also used for a several other purposes including taste-and-odor control, color removal, iron and manganese oxidation, turbidity removal, algal removal, increasing the biodegradability of natural organic matter (NOM), and oxidation of specific micropollutants (Araújo et al., 2016; Bhatta et al., 2015; Bukhari et al., 2019; Freitas-Silva et al., 2013; Lage Filho, 2010).

Once dissolved in water, the ozone reacts with a large number of organic compounds in two different possible ways: direct oxidation, such as molecular ozone, or indirect reaction through the formation of secondary oxidants, such as free radicals, particularly the hydroxyl radical (Subha and Muthukumar, 2012; Wajahat et al., 2019).

Despite the importance of ozone, it is noteworthy that the use of innovative technologies such as biogenic nanoparticles (BNPs), magnetotactic bacteria (MTB), and Phytogenic Magnetic Nanoparticles (PMNPs) is increasing in wastewater treatment, especially in the removal of heavy metals and specific compounds. In this way, studies related to ozonation should take into account all drawbacks including high cost, complex operation, and toxic and chemical reducing agents required to synthesize and control system operation (Ali et al., 2017; 2018).

Considering the importance of ozonation in wastewater treatment, whether domestic or industrial, the objective of this paper was to evaluate the application of different dosages and exposure times to ozone on physical and chemical attributes in domestic sewage effluent, obtained after Root Zone Wastewater Treatment (RZWT).

\section{MATERIAL AND METHODS}

The Root Zone Wastewater Treatment (RZWT) is located at the Água Limpa Farm (ALF) of the University of Brasília (UnB) (15 57'16" S, 47 55'89' W and altitude of $1.103 \mathrm{~m}$ ). The Laboratory of Water Analysis and the Laboratory of Storage and Preprocessing of Agricultural Products of the Faculty of Agronomy and Veterinary Medicine (UnB) performed the analyses of the effluent before and after applying ozonation.

The effluent generated at the Água Limpa Farm is mostly from sanitary discharges and a refectory, which, for its composition, is characterized as domestic effluent. The daily volume 
generated is quite variable due to its frequency of use and oscillation of amount of people who attend the ALF, and it is not equal among the days of the week.

The RZWT consists of a set of four equal units built in rectangular fiberglass structures, with dimensions of $2.5 \mathrm{~m}$ (width), 6.5 (length) and $0.5 \mathrm{~m}$ (height). The first unit was cultivated with taboa (Typha spp); the second with Brazilian Papyrus (Cyperus Giganteus); the third with umbrella papyrus (Cyperus alternifolius), and a fourth system without a plant (witness).

An ozone generator O\&LM, Ozone \& Life ${ }^{\circledR}$ brand generated the ozone gas. In the process of gas generation, oxygen $90 \%$ pure and humidity free was used as input, obtained from the Mark Plus Oxygen Concentrator.

In order to produce the ozone gas $\left(\mathrm{O}_{3}\right)$, the oxygen went through a refrigerated reactor, in which the Dielectric Barrier Discharge (DBD) occurs. This type of discharge consists in applying a high voltage between two parallel electrodes, having between them a dielectric (glass) and a free space. In this free space, a discharge is produced in the form of filaments, where electrons are generated with sufficient energy to produce the breakdown of the oxygen molecules, forming the ozone $\left(\mathrm{O}_{3}\right)$ (Lage Filho et al., 2008).

To evaluate the effect of exposure times of ozonation (0, 30, 60, 90, 120 and 150 minutes) and to optimize the analyses, two glass containers were used in each stage, where $\mathrm{O}_{3}$ was equally divided. The containers were hermetically sealed and had $10 \mathrm{~cm}$ of internal diameter and $20 \mathrm{~cm}$ of useful height, having in its plastic cover, a porous diffuser through which the gas was introduced in a flow of $1.0 \mathrm{~L} \mathrm{~min}^{-1}$.

The first two treatments were the exposure times of 30 and 90 min (one in each container). As soon as the time of $30 \mathrm{~min}$ finished, it was replaced by the $60 \mathrm{~min}$ treatment, thus, at the end of the $90 \mathrm{~min}$, four treatments had already been completed ( 0 - witness, 30, 60 and $90 \mathrm{~min}$ ). The last two treatments $(120$ and $150 \mathrm{~min})$ followed the same sequence. At the end of the 120 min treatment, this container was replaced with distilled water until the completion of the experiment, i.e., for another $30 \mathrm{~min}$ until the treatment of $150 \mathrm{~min}$ was completed.

For the treatment with different dosages of ozone $\left(0,4,10,17,25\right.$ and $3 \mathrm{mg} \mathrm{L}^{-1}$ of $\left.\mathrm{O}_{3}\right)$, only one container was used. The treatments performed consecutively from the lowest to the highest dosage. The first effluent sample was exposed to a dosage of $4 \mathrm{mg} \mathrm{L}^{-1}$ of $\mathrm{O}_{3}$ for $30 \mathrm{~min}$, the second sample was added and the dosage was increased from 4 to $10 \mathrm{mg} \mathrm{L}^{-1}$ which remained for more $30 \mathrm{~min}$. The dosages of 17, 25 and $35 \mathrm{mg} \mathrm{L}^{-1}$ of $\mathrm{O}_{3}$ followed the same sequence.

In order to carry out the laboratory analyses, the methodologies of analysis of the Standard Methods for the Examination of Water and Wastewater (APHA et al., 2005) were used or adapted. APHA Method no. 4500-0 (for Dissolved Oxygen); no. 2320 (for Total Alkalinity); no. 2130 (for Turbidity); no. 2120 (for Color); no. 2540 (for Solids); no. $4500-\mathrm{NO}_{3}$ (for Ammonia); no. 3500 - Na (for Sodium); and no. 3500 - K (for Potassium). To apply different exposure times to $\mathrm{O}_{3}$, four collection campaigns were carried out in November 2017, and to evaluate the different dosages of $\mathrm{O}_{3}$, three collection campaigns were carried out in December 2017. In each campaign, $6 \mathrm{~L}$ of effluent in sterilized containers were collected, always at 1 p.m. due to higher volume of sewage at this time. The containers were packed in ice packs, which were transported to the laboratory and refrigerated at $4^{\circ} \mathrm{C}$ (APHA et al., 2005).

The results of the experiments were analyzed using the Software Assistant (Silva and Azevedo, 2016), applying the Duncan test at 1 and 5\% of probability, considering the collection dates as the replicates.

\section{RESULTS AND DISCUSSION}

\subsection{Potential Hydrogen (pH)}

There was an increase in $\mathrm{pH}$ values in the effluent samples, either as a function of exposure times due to the variation of the ozone dosages (Figure 1). 
The $\mathrm{pH}$ values of the effluent exposed to the times of ozonation were higher than the effluent without ozonation, being the largest of 8.38 and the lowest of 7.46 (without ozonation). The time of $30 \mathrm{~min}$ differed from the times of 90, 120 and $150 \mathrm{~min}$. A variation of $8.7 \%$ might be observed for the time of $30 \mathrm{~min}$, up to $12.3 \%$ for the times of 120 and $150 \mathrm{~min}$, demonstrating that the greatest variation occurred up to $30 \mathrm{~min}$, after the beginning of $\mathrm{O}_{3}$ application (Figure $1)$.
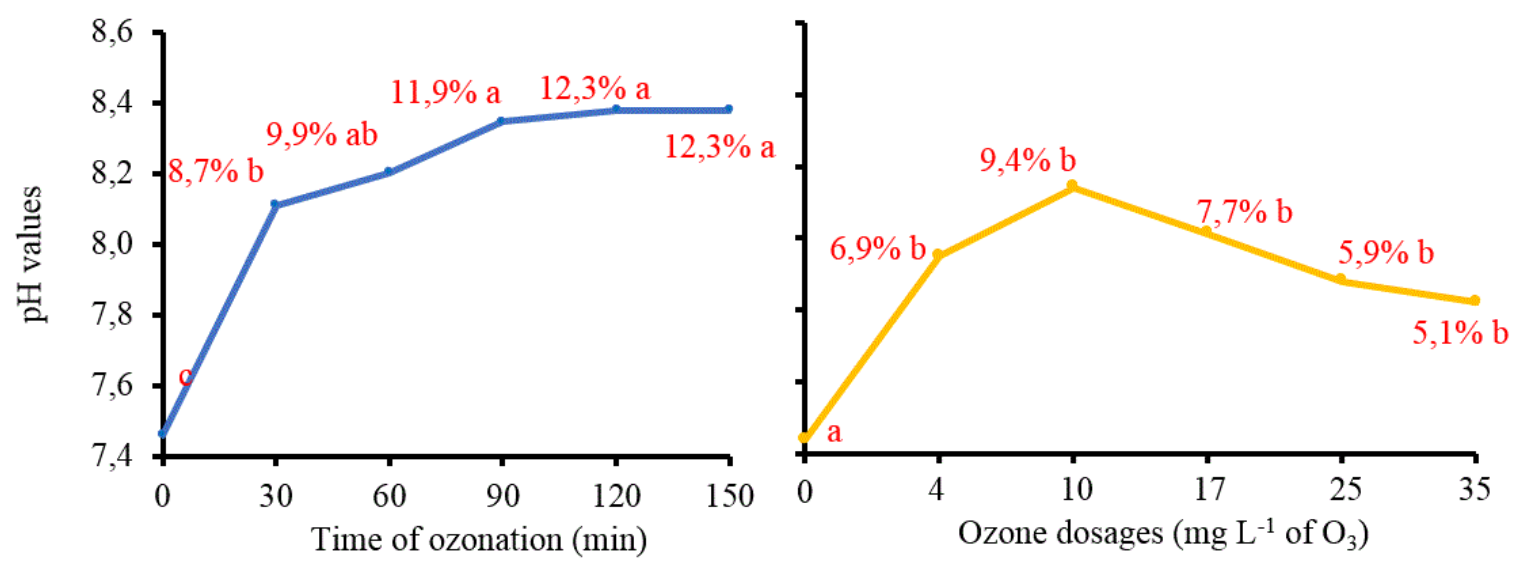

Figure 1. $\mathrm{pH}$ values of the domestic sewage effluent as a function of the exposure times 0, 30, 60, 90,120 and $150 \mathrm{~min}$ at the dosage of $12 \mathrm{mg} \mathrm{L}^{-1}$ of $\mathrm{O}_{3}$ and to the dosages of $0,4,10,17,25$ and $35 \mathrm{mg} \mathrm{L}^{-1}$ of $\mathrm{O}_{3}$ for $30 \mathrm{~min}$ and variation, in $\%$, in relation to the effluent without ozonation. Different letters between the times of ozonation or $\mathrm{O}_{3}$ dosages differ from each other by the Duncan test at $1 \%$ probability.

As the $\mathrm{O}_{3}$ dosages varied, the $\mathrm{pH}$ values increased, reaching $8.14\left(10 \mathrm{mg} \mathrm{L}^{-1}\right.$ of $\left.\mathrm{O}_{3}\right)$, differing from the effluent without ozonation, but equal to the other dosages. After the dosage of $10 \mathrm{mg} \mathrm{L}^{-1}$ of $\mathrm{O}_{3}$, a reduction in the $\mathrm{pH}$ values was observed until the highest dosage evaluated (35 $\mathrm{mg} \mathrm{L}^{-1}$ of $\mathrm{O}_{3}$ ), but not significantly (Figure 1). The $\mathrm{pH}$ drop from the $25 \mathrm{mg} \mathrm{L}^{-1} \mathrm{O}_{3}$ dosage can be attributed to the formation of short chain acid compounds (acetic and oxalic acid, for example), resulting from the partial oxidation of more complex substances promoted by ozone as observed by Aquino and Pires (2016).

As ozone acts on the effluent, there is the release of hydroxide ions $\left(\mathrm{OH}^{-}\right)$making these predominant over hydrogen $\mathrm{H}^{+}$ions. When the $\mathrm{pH}$ reaches 8.0, practically half of the $\mathrm{O}_{3}$ introduced is decomposed into several intermediate forms of oxygen, over a period of $10 \mathrm{~min}$ (Lage Filho et al., 2008; Coelho et al., 2015).

This fact may explain the increase in $\mathrm{pH}$ values in the effluent samples with variation of the exposure time. When the $\mathrm{pH}$ value of the effluent is above 8.0, most of the ozone is decomposed into $\mathrm{OH}^{-}$, which induces an increasingly alkaline condition, interfering with the attributes of the effluent sample.

Bhatta et al. (2015) observed a slight increase in $\mathrm{pH}$ values in their study on the treatment of wastewater by ozone produced in dielectric barrier discharge, in agreement with the results found here. Likewise, Silva and Daniel (2015) observed an increase in $\mathrm{pH}$ values $(\mathrm{p}=0.05)$ for the ozonized effluents compared to the UASB reactor effluent.

\subsection{Electrical Conductivity (EC) and Total Alkalinity}

Ozonation promoted a significant reduction in EC values as a function of time of ozonation and a reduction of Alkalinity as a function of $\mathrm{O}_{3}$ dosages (Figure 2).

As the time of exposure of the effluent to the $\mathrm{O}_{3}$ increased, there was a reduction of $7.5 \%$ in the EC values at 120 min compared to the effluent without exposure to $\mathrm{O}_{3}$. The grand mean 
of the treatment for different ozone dosages was $1281 \mu \mathrm{S} \mathrm{cm}^{-1}$, with values ranging from 1295 ( $0 \mathrm{mg} \mathrm{L}^{-1}$ of $\left.\mathrm{O}_{3}\right)$ to $1272\left(17 \mathrm{mg} \mathrm{L}^{-1}\right.$ of $\left.\mathrm{O}_{3}\right)$, but not differing between dosages.

Regarding total alkalinity, the grand mean obtained by the different exposure times was $56 \mathrm{mg} \mathrm{L}^{-1}$ of $\mathrm{CaCO}_{3}$, with values ranging from 53 to $59 \mathrm{mg} \mathrm{L}^{-1}$ of $\mathrm{CaCO}_{3}$, showing no significant difference by the $1 \%$ Duncan test.
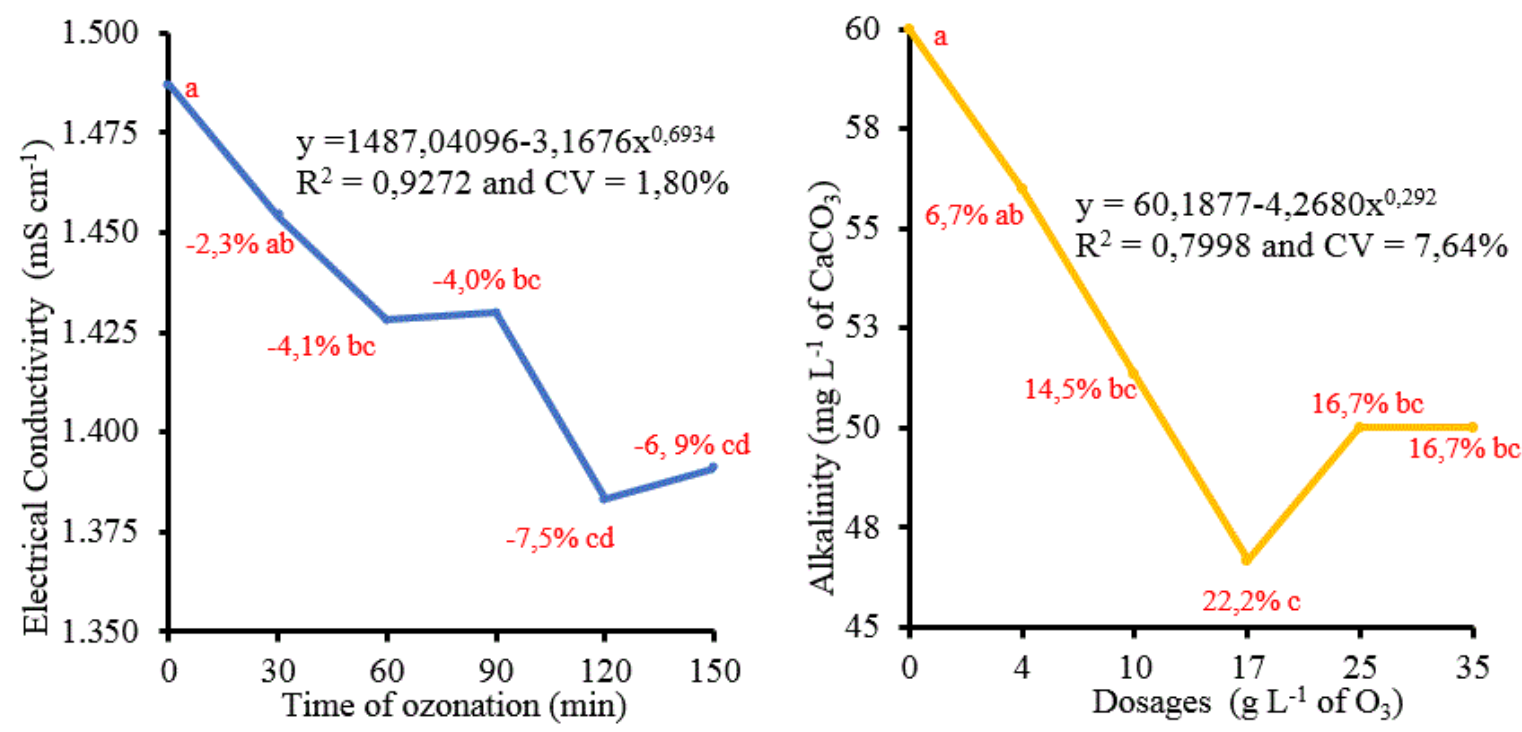

Figure 2. Electrical Conductivity of the domestic sewage effluent as a function of the exposure times of $0,30,60,90,120$ and $150 \mathrm{~min}$ at the dosage of $12 \mathrm{mg} \mathrm{L}^{-1}$ of $\mathrm{O}_{3}$, and total alkalinity as a function of the time of exposure of the effluent at the dosages of $0,4,10,17,25$ and $35 \mathrm{mg} \mathrm{L}^{-1}$ of $\mathrm{O}_{3}$ for $\quad 30 \mathrm{~min}$ and variation, in $\%$, in relation to the effluent without ozonation. Different letters between times of ozonation or $\mathrm{O}_{3}$ dosages differ from each other by the Duncan test at $1 \%$ probability.

In the treatment as a function of the $\mathrm{O}_{3}$ dosages, there was a reduction in the alkalinity values with the increase in the ozone dosages up to $17 \mathrm{mg} \mathrm{L}^{-1}$, tending to stabilize from this dosage. The grand mean in the treatment was $52.33 \mathrm{mg} \mathrm{L}^{-1}$ of $\mathrm{CaCO}_{3}$, with values ranging from $46.67 \mathrm{mg} \mathrm{L}^{-1}$ (17 $\mathrm{mg} \mathrm{L}^{-1}$ of $\mathrm{O}_{3}$ dosage) to $60 \mathrm{mg} \mathrm{L}^{-1}$ (without ozonation), an average reduction of $22.2 \%$ (Figure 2).

Considering the basic $\mathrm{pH}$ values in both treatments, the buffering power (alkalinity) of the effluent treated with $\mathrm{O}_{3}$ is adequate. It is worth highlighting that alkalinity is not the standard classification for natural waters or emission of sewage, showing the importance of this parameter in the control of certain unit processes used in water treatment plants (Von Sperling, 2014).

\subsection{Dissolved Oxygen (DO)}

The Dissolved Oxygen (DO) values were higher at all times of ozonation and at all $\mathrm{O}_{3}$ dosages compared with the effluent without ozonation (Figure 3).

The grand mean in the treatment as a function of time of exposure to $\mathrm{O}_{3}$ was $15.16 \mathrm{mg} \mathrm{O}_{2} \mathrm{~L}^{-1}$, with values ranging from 5.5 to $19.3 \mathrm{mg} \mathrm{O}_{3} \mathrm{~L}^{-1}$ for 0 and $90 \mathrm{~min}$, respectively, representing elevation of $351 \%$. While at the exposure times of 30,60, 120 and $150 \mathrm{~min}$ the increases were 253, 282, 349 and $318 \%$, respectively (Figure 3).

The grand mean when varying the $\mathrm{O}_{3}$ dosages was $21.28 \mathrm{mg} \mathrm{O}_{3} \mathrm{~L}^{-1}$, with values ranging from 6.2 to $26.2 \mathrm{mg} \mathrm{O}_{3} \mathrm{~L}^{-1}$. There was an increase in DO values of $424 \%\left(17 \mathrm{mg} \mathrm{L}^{-1} \mathrm{O}_{3}\right)$ and $413 \%\left(25 \mathrm{mg} \mathrm{L}^{-1} \mathrm{O}_{3}\right)$ in relation to the effluent without ozonation. 

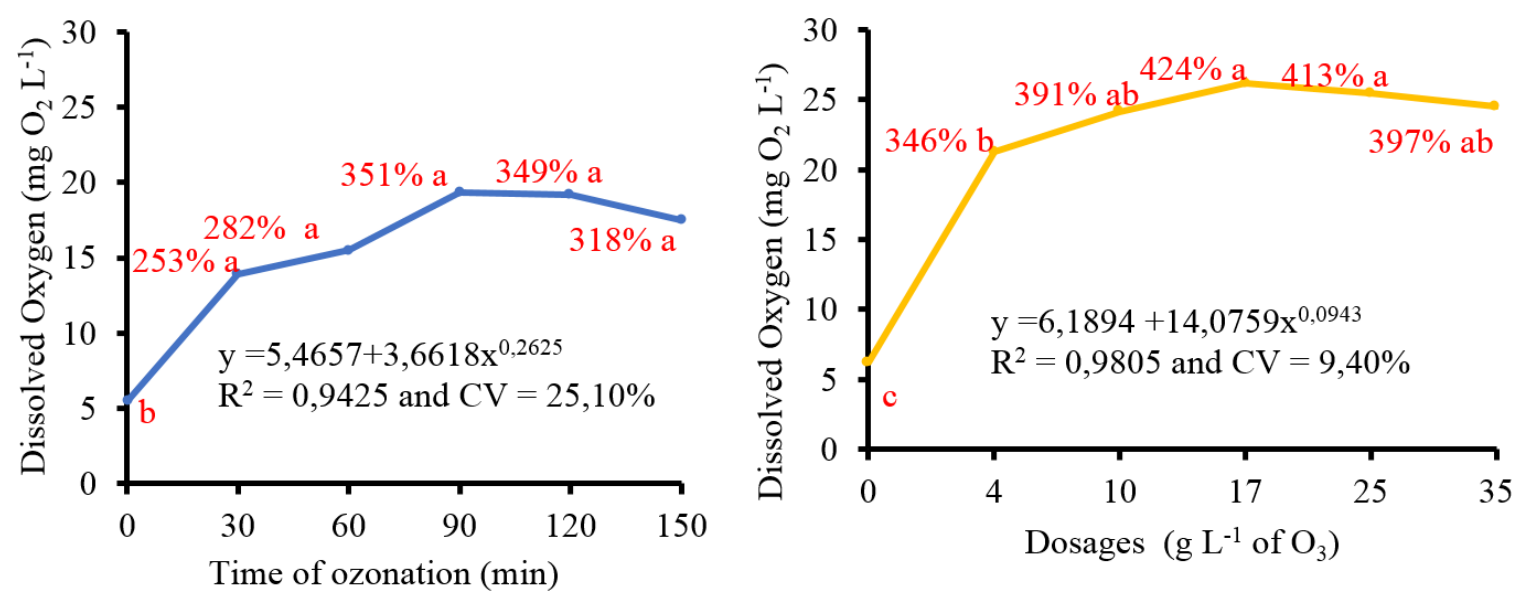

Figure 3. Dissolved Oxygen $\left(\mathrm{mg} \mathrm{O}_{2} \mathrm{~L}^{-1}\right)$ of the domestic sewage effluent as a function of times of the exposure of $0,30,60,90,120$ and $150 \mathrm{~min}$ at the dosage of $12 \mathrm{mg} \mathrm{L}^{-1}$ of $\mathrm{O}_{3}$ and as a function of the dosages of $0,4,10,17,25$ and $35 \mathrm{mg} \mathrm{L}^{-1}$ of $\mathrm{O}_{3}$ for $30 \mathrm{~min}$ and variation, in $\%$, in relation to the effluent without ozonation. Different letters between times of ozonation and $\mathrm{O}_{3}$ dosage differ from each other by the Duncan test at $1 \%$ probability.

The significant increase in DO as a function of the time of exposure and to the $\mathrm{O}_{3}$ dosages is explained by the fact that the $\mathrm{O}_{3}$ applied to the effluent is rapidly converted into $\mathrm{O}_{2}$, raising its concentration in the environment. This phenomenon was also observed by Bhatta et al. (2015) where the DO values of the effluent, after the treatment with ozone, increased significantly, reaching the value of $9.55 \mathrm{mg} \mathrm{O}_{2} \mathrm{~L}^{-1}$ in that study.

\subsection{Turbidity}

There was a decrease in the turbidity values in the effluent samples both in relation to the exposure times and in relation to $\mathrm{O}_{3}$ dosages (Figure 4).
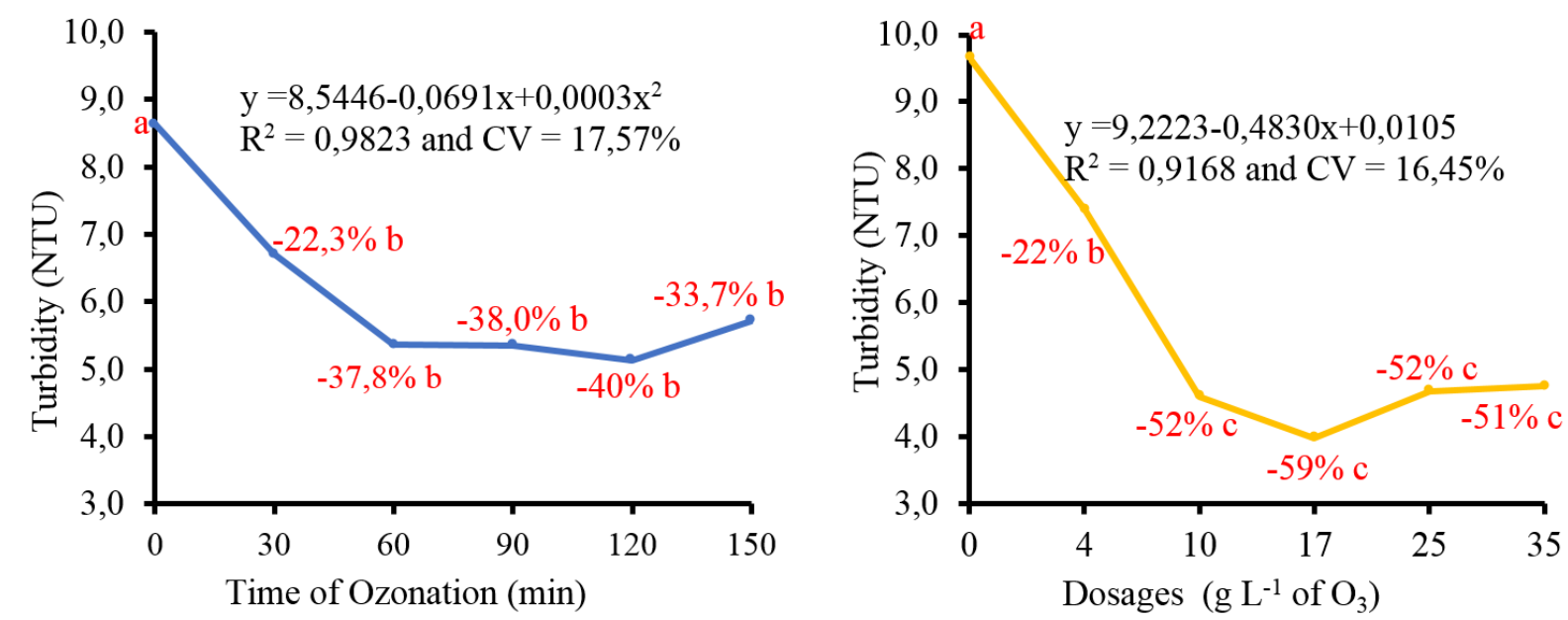

Figure 4. Turbidity in NTU of domestic sewage effluent treated as a function of the exposure times of $0,30,60,90,120$ and $150 \mathrm{~min}$ at the dosage of $12 \mathrm{mg} \mathrm{L}-1$ of $\mathrm{O}_{3}$ and as a function of the dosages of 0 , $4,10,17,25$ and $35 \mathrm{mg} \mathrm{L}^{-1}$ of $\mathrm{O}_{3}$ for $30 \mathrm{~min}$ and variation, in \%, in relation to the effluent without ozonation. Different letters between times of ozonation and $\mathrm{O}_{3}$ dosages differ from each other by the Duncan test at $1 \%$ probability.

The grand mean in treatment as a function of time of exposure was $6.2 \mathrm{NTU}$, being the highest value 8.63 and the lowest $5.1 \mathrm{NTU}$ (0 and $120 \mathrm{~min}$ of exposure), representing a reduction of $40.0 \%$. 
As a function of the $\mathrm{O}_{3}$ dosages, the grand mean of turbidity was $5.8 \mathrm{NTU}$, representing a reduction of $23.42 \%$ in the dosage of $\mathrm{mg} \mathrm{L}^{-1}$ of $\mathrm{O}_{3}$, and of $52.43 \%$ and $58.86 \%$ in the dosages 25 and $35 \mathrm{mg} \mathrm{L}^{-1}$ of $\mathrm{O}_{3}$, respectively (Figure 4).

In this study, the greatest reductions in turbidity values were $40.0 \%$ and $58.9 \%$ at $120 \mathrm{~min}$ of exposure and $17 \mathrm{mg} \mathrm{L}^{-1}$ of $\mathrm{O}_{3}$, respectively. Cabrera-Díaz et al. (2016) observed higher turbidity removal values, reaching $99.2 \%$ in combined treatment of vinasse (anaerobic filterreactor and ozonation process); however, using a concentration of $100 \mathrm{mg} \mathrm{L}^{-1}$ of $\mathrm{O}_{3}$ and a contact period of 3 hours.

The reason for the decreasing values of turbidity while increasing ozone dosages and exposures times are that some particles and high weight organic compounds would be destroyed by ozone and converted into dissolved compounds like observed by Xu et al. (2002).

The reduction in turbidity values were positive, considering there was a reduction close to $60.0 \%$ in the dosage of $17 \mathrm{mg} \mathrm{L}^{-1}$ of $\mathrm{O}_{3}$ for $30 \mathrm{~min}$. On the other hand, Li et al. (2015), in a study on biofiltration and ozonation for effluent treatment, observed a turbidity reduction of $90.0 \%$ using a dosage of $5 \mathrm{mg} \mathrm{L}^{-1}$ of $\mathrm{O}_{3}$ and a flow of $1.5 \mathrm{~m}^{3} \mathrm{~h}^{-1}$, respecting local limits for the discharge of urban effluents into water bodies.

\subsection{Color}

There was a reduction in color values at all exposure times and at all ozone dosages (Figure $5)$.

The grand mean of the color as a function of exposure times to $\mathrm{O}_{3}$ was 96.0 of standard APHA color with progressive reduction, reaching 49.7 at $120 \mathrm{~min}$ of exposure. In percentage, the reduction was $47.0 \%$ at $30 \mathrm{~min}$ and $76.2 \%$ at $120 \mathrm{~min}$

Regarding the treatment with different dosages of ozone, there was a reduction of $67.7 \%$ at the dosage of $4 \mathrm{mg} \mathrm{L}^{-1}$ of $\mathrm{O}_{3}$ and of $81.5 \%$ at the dosage of $17 \mathrm{mg} \mathrm{L}^{-1}$ of $\mathrm{O}_{3}$ (Figure 5).
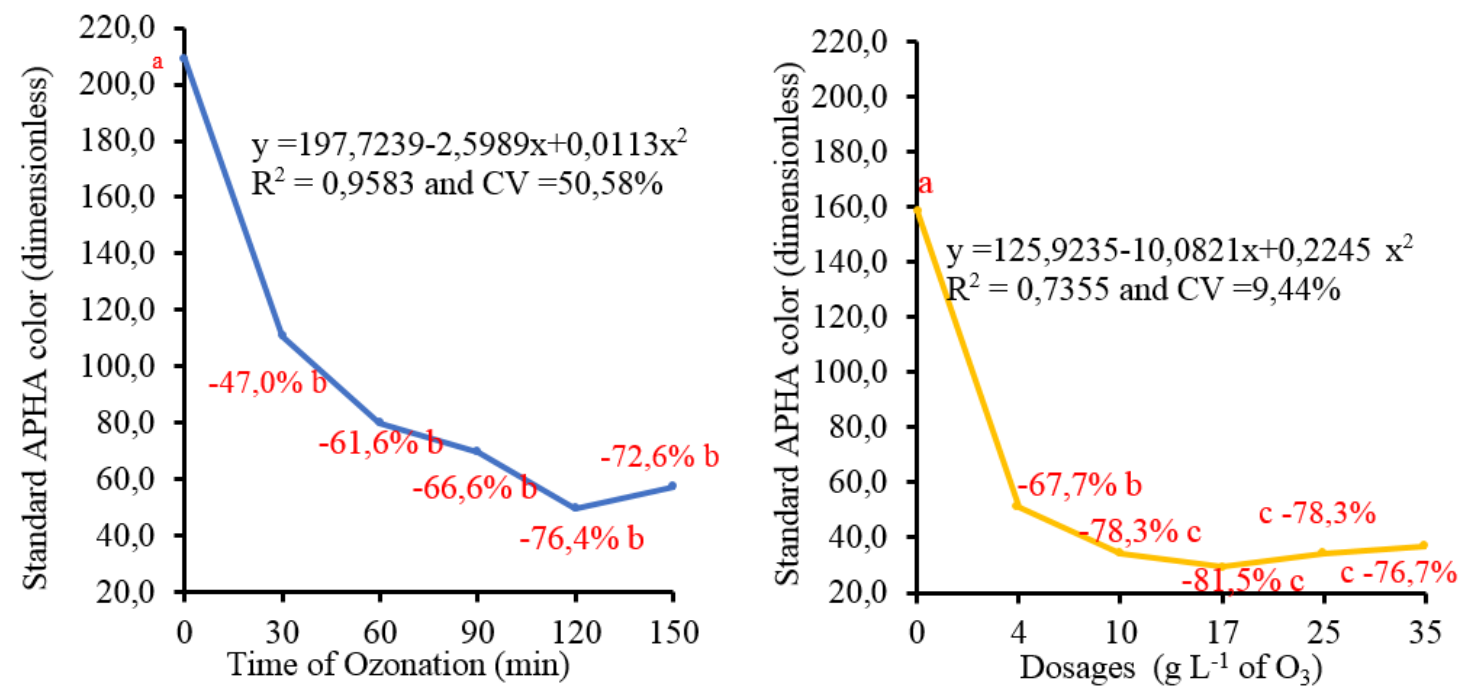

Figure 5. Standard APHA color (dimensionless) values of treated domestic sewage effluent as a function of the exposure times of $0,30,60,90,120$ and $150 \mathrm{~min}$ at the dosage of $12 \mathrm{mg} \mathrm{L}^{-1}$ of $\mathrm{O}_{3}$ and as a function of the dosages of $0,4,10,17,25$ and $35 \mathrm{mg} \mathrm{L}^{-1}$ of $\mathrm{O}_{3}$ for 30 min and variation, in \%, in relation to the effluent without ozonation. Different letters between times of ozonation and dosages of $\mathrm{O}_{3}$ differ from each other by the Duncan test at $1 \%$ probability.

The greatest color reductions (76.2\% and $81.5 \%)$, are corroborated by Cabrera-Díaz et al. (2016) and Li et al. (2015), in which Cabrera-Díaz et al. (2016) observed color removals of 93.7\% (UPt-Co) in a combined treatment of vinasse (anaerobic filter-reactor and ozonation process) emphasizing the effectiveness of the ozonation process in the color and turbidity 
removal of this residue. Li et al. (2015), on the other hand, using biofiltration and ozonation for effluent treatment, observed a general efficiency for color removal of $70.0 \%$, similar to the one obtained in the present study. Bhatta et al. (2015) observed visually, in their study on the treatment of wastewater by ozone, that the ozonized samples went from a dark gray color to a light color, close to the standard color of the water.

\subsection{Ammonia, Sodium, Potassium and Total Solids}

The average values of ammonia, sodium, potassium and total solids were not influenced as a function of exposure times and $\mathrm{O}_{3}$ dosages.

Considering the average values, there was a tendency of ammonia elevation in absolute values, and there was no statistical difference, attributed, in part, to the great variability of the results, i.e, there was no consistent evidence that the time of ozonation and the $\mathrm{O}_{3}$ dosages have influence on the ammonia contents.

Regarding sodium and potassium, there was great homogeneity of the values, both as a function of time and of $\mathrm{O}_{3}$ dosages, i.e., parameters that were not influenced by ozonation.

The total solids, although showing some variations between the exposure times and $\mathrm{O}_{3}$ dosages, did not present significant differences, leading to the conclusion, as well as in the parameters ammonia, sodium and potassium, that ozonation does not influence their values.

\section{CONCLUSIONS}

Ozonation reduced color and turbidity values both as a function of exposure times and as a function of $\mathrm{O}_{3}$ dosages. There was a maximum reduction of $76.2 \%$ in color at $120 \mathrm{~min}$ of exposure and of $81.5 \%$ in turbidity at the concentration of $17 \mathrm{mg} \mathrm{L}^{-1}$ of $\mathrm{O}_{3}$.

There was an increase in $\mathrm{pH}$, Total Alkalinity and Dissolved Oxygen (OD) values. At 120 min of exposure, there was a $12.30 \%$ increase in $\mathrm{pH}$ and at the dose of $4 \mathrm{mg} \mathrm{L}^{-1}$ of $\mathrm{O}_{3}$ the increase was $9.4 \%$. Alkalinity increased $22.2 \%$ at the dose of $17 \mathrm{mg} \mathrm{L}^{-1}$ of $\mathrm{O}_{3}$, whereas OD values increased $351 \%$ at 90 min of exposure and $424 \%$ at the dose of $17 \mathrm{mg} \mathrm{L}^{-1}$ of $\mathrm{O}_{3}$.

Potassium, sodium, ammonia and total solids were not influenced by exposure time and ozone dosages.

\section{ACKNOWLEDGMENTS}

To CNPq for the financial assistance. Universal Call - MCTI / CNPq No 14/2013. Process: 480332 / 2013-4.

\section{REFERENCES}

ALI, I.; PENG, C.; KHAN, Z. M.; NAZ, I.; SULTAN, M. An overview of heavy metal removal from wastewater using magnetotactic bacteria. Journal of Chemical Technology \& Biotechnology, v. 93, n. 10, p. 2817-2832, 2018.

ALI, I.; PENG, C.; NAZ, I.; KHAN, Z. M.; SULTAN, M.; ISLAM, T.; ABBASI, I. A. Phytogenic magnetic nanoparticles for wastewater treatment: a review. RSC Advances, v. 7, n. 64, p. 40158-40178, 2017.

AQUINO, S.; PIRES, E. C. Assessment of ozone as a pretreatment to improve anaerobic digestion of vinasse. Brazilian Journal of Chemical Engineering, v. 33, n. 2, p. 279$285,2016$.

APHA; AWWA; WPCF. Standard methods for the examination of water and wastewater. 21. ed. Washington D.C., 2005.

Rev. Ambient. Água vol. 14 n. 2, e2328 - Taubaté 2019 
ARAÚJO, K. S. D.; ANTONELLI, R.; GAYDECZKA, B., GRANATO, A. C.; MALPASS, G. R. P. Advanced oxidation processes: a review of fundamentals and applications in the treatment of urban and industrial wastewaters. Revista Ambiente \& Água, v. 11, n. 2, p. 387-401, 2016.

BHATTA, R.; KAYASTHA, R.; SUBEDI, D. P.; JOSHI, R. Journal of Chemistry, v. 2015, 6 p., 2015. https://doi.org/10.1155/2015/648162

BUKHARI, K.; AHMAD, N.; SHEIKH, I. A.; AKRAM, T. M. Effects of Different Parameters on Photocatalytic Oxidation of Slaughterhouse Wastewater Using TiO. Polish Journal $\begin{array}{llllllll}\text { of Environmental Studies, } & \text { v. 28, } & \text { n. } 3, & \text { p. } & 1-10,\end{array}$ http://dx.doi.org/10.15244/pjoes/90635

CABRERA-DÍAZ, A.; PEREDA-REYES, I.; DUEÑAS-MORENO, J.; VÉLIZ-LORENZO, E.; DÍAZ-MARRERO, M. A.; MENÉNDEZ-GUTIÉRREZ, C. L.; ZAIAT, M. Combined treatment of vinasse by an upflow anaerobic filter-reactor and ozonation process. Brazilian Journal of Chemical Engineering, v. 33, n. 4, p. 753-762, 2016.

COELHO, C. C. de S.; FREITAS-SILVA, O.; CAMPOS, R. D. S.; BEZERRA, V. S.; CABRAL, L. M. Ozonização como tecnologia pós-colheita na conservação de frutas e hortaliças: Uma revisão. Revista Brasileira de Engenharia Agrícola e Ambiental, v. 19, n. 4, p. 369-375, 2015.

FREITAS-SILVA, O.; MORALES-VALLE, H.; VENÂNCIO, A. Potential of Aqueous Ozone to Control Aflatoxigenic Fungi in Brazil Nuts. ISRN biotechnology, v. 2013, 6 p., 2013. https://dx.doi.org/10.5402/2013/859830

KADLEC, R. H.; WALLACE, S. Treatment wetlands. $2^{\text {nd }}$ ed. Boca Raton: CRC press, 2009. p. 03-05.

LAGE FILHO, F. A. Avaliação da filtração e ozonização de efluente sanitário primário: aspectos de inativação microbiana e variáveis de ozonização. Química Nova, v. 31, n. 2, p. 312-316, 2008.

LAGE FILHO, F. A. Ozone application in water sources: effects of operational parameters and water quality variables on ozone residual profiles and decay rates. Brazilian Journal of Chemical Engineering, v. 27, n. 4, p. 545-554, 2010.

LI, X.; SHI, H.; LI, K.; ZHANG, L. Combined process of biofiltration and ozone oxidation as an advanced treatment process for wastewater reuse. Frontiers of Environmental Science \& Engineering, v. 9, n. 6, p. 1076-1083, 2015.

SILVA F. A. S.; AZEVEDO C. A. V. The Assistat Software Version 7.7 and its use in the analysis of experimental data. African Journal Agricultural Research, v. 11, n. 39, p. 3733-3740, 2016. http://dx.doi.org/10.5897/AJAR2016.11522

SILVA, G. H. R.; DANIEL, L A. Desinfecção de efluente anaeróbio com o uso de ozônio/cloro. Engenharia Sanitária e Ambiental. v. 20, n. 2, p. 279-288. 2015. http://dx.doi.org/10.1590/S1413-41522015020000083662

SUBHA, B.; MUTHUKUMAR, M. Optimization of ozonation process for the reduction of excess sludge production from activated sludge process of sago industry wastewater using central composite design. The Scientific World Journal, v. 2012, 8 p., 2012. http://dx.doi.org/10.1100/2012/239271 
VON SPERLING, M. Características das águas residuárias. In: VON SPERLING, M. Introdução à qualidade das águas e ao tratamento de esgotos. Belo Horizonte: DESA; UFMG, 2014. p. 24-42, 82-126.

XU, P.; JANEX, M. L.; SAVOYE, P.; COCKX, A.; LAZAROVA, V. Wastewater disinfection by ozone: main parameters for process design. Water Research, v. 36, n. 4, p. 10431055, 2002.

WAJAHAT, R.; YASAR, A.; KHAN, A. M.; TABINDA, A. B.; BHATTI, S. G. Ozonation and Photo-Driven Oxidation of Ciprofloxacin in Pharmaceutical Wastewater: Degradation Kinetics and Energy Requirements. Polish Journal of Environmental Studies, v. 28, n. 3 p. 1-6, 2019. http://dx.doi.org/10.15244/pjoes/90597 